\title{
ANTIDIABETIC ACTIVITY OF ETHANOLIC EXTRACT OF Kalanchoe pinnata LEAVES IN ALLOXAN INDUCED HYPERGLYCAEMIC RATS
}

\author{
Tri Yuliani, Indah D. Dewijanti, Sofna D.S. Banjarnahor
}

Research Center for Chemistry, Indonesian Institute of Sciences (LIPI), Kawasan PUSPITEK, Muncul, Serpong, Kota Tangerang Selatan, Banten 15314

Submitted: $13-5-2016$

Revised: 25-07-2016

Accepted: 11-09-2016

*Corresponding author Tri Yuliani

Email: anik_baik@yahoo.com

\begin{abstract}
Diabetes remains a major burden in health care both in developed and developing countries. Kalanchoe pinnata has been used as a traditional medicine to treat diabetes. The aim of this study to find scientific evidence of antidiabetic activity of Kalanchoe pinnata extract (KPE) through hypoglycemic effect using animal model of diabetes mellitus. Hyperglycaemia was developed in rats using alloxan $150 \mathrm{mg} / \mathrm{kgBW}$. Three days after alloxan injection, rats having fasting blood glucose (FBG) $>200 \mathrm{mg} / \mathrm{dL}$ were divided into six groups, namely HG (hyperglycaemia), HG+KPE high-dose (hyperglycaemia+ $\mathrm{KPE} 33.2 \mathrm{mg} / \mathrm{kg}$ ), HG+KPE medium-dose (hyperglycaemia+ KPE $11.6 \mathrm{mg} / \mathrm{kg}$ ), $\mathrm{HG}+\mathrm{KPE}$ low-dose (hyperglycaemia+ $\mathrm{KPE} 5.8 \mathrm{mg} / \mathrm{kg}$ ), standard drug 1 (hyperglycaemia+glibenclamide $1.35 \mathrm{mg} / \mathrm{kg}$ ), standard drug 2 (hyperglycaemia+acarbose $13.5 \mathrm{mg} / \mathrm{kg}$ ). Then, FBG was measured every 5 days recorded as $t 1, t 2$, and $t 3$ to determine fluctuations in blood glucose. At the end of the study, rats were sacrified, pancreas was collected and number of pancreatic beta cell langerhans was determined. KPE $11.6 \mathrm{mg} / \mathrm{kg}$ showed best hypoglycemic effect and improvement of the number of pancreatic beta cell langerhans. KPE has hypoglycemic effect through improvement of the number of pancreatic beta cell langerhans but not in dose dependent manner.
\end{abstract}

Key words: Antidiabetic, Kalanchoe pinnata, hyperglycaemic, alloxan, pancreatic

\section{INTRODUCTION}

WHO (2015) reported 9\% people aged $18+$ worldwide suffered from diabetes, while in Indonesia the prevalence was only $1.5 \%$ (Kemenkes RI, 2013). It is worth noticing that this disease is a burden of health care in both developed and developing countries (Abdulazeez et al., 2013). Diabetes develops from prolong glucose imbalance between intracellular and extracellular resulted in hyperglycaemia state in which blood glucose can not be utilized by living cells. These conditions lead to vascular complication through increasing oxidative stress and inflammation. Vascular complication is the leading cause of death in both diabetes type 1 and type 2 patient (Domingueti et al., 2015).

Diabetes mellitus (DM) are classified as two major disease: type $1 \mathrm{DM}$ and type $2 \mathrm{DM}$. Type $1 \mathrm{DM}$ is an autoimmune disease that immune system of the body attack insulin producing pancreatic $\beta$ cells resulting in low insulin production. This condition leads to insulin dependent DM. In the other hand, type 2 DM was caused by inadequate action of insulin in action site (Hossain et al., 2016).

Pharmacotheraphy in DM patient does not eliminate the cause of the disease but its targets on the symptom using insulin and hypoglicemic agent such as sulfonylurea and biguanids (Abdulazeez et al., 2013; Verma et al, 2015). However, sulfonylurea exert several adverse effect such as hypoglicemia and weight gain, in addition to toxic effect on liver and renal, while metformin cause lactic acidosis (Verma et al., 2015).

Alloxan is widely used in experimental pharmacology to induce diabetes in rat. The pathological mechanism is by destruction of insulin producing pancreatic $\beta$-cells. Alloxan undergo redox reaction resulted in increase increasing of radical species. In this case, pancreatic $\beta$-cells is the most sensitive organ 
towards these radical attacks. Hyperglycaemia state does not occur immediately. At first, alloxan induces insulin release independent of glucose level. However, this effect is followed by suppression of the islet respons to even high level of glucose leading to hyperglycaemia state (Szkudelski et al., 2001).

Nowadays, the need for safe and effective drugs has brought natural product as the promising source of companion drug for diabetes (Sharma and Gupta, 2015). Kalanchoe pinnata has been traditionally used worldwide as medicinal plants, including to treat diabetes (Patil et al., 2013). Our previous study reveals its antidiabetic activity through inhibition of $\alpha$-glucosidase with $\mathrm{IC}_{50} \sim 16.12 \mathrm{ppm}$. Meanwhile, radical scavenger activity using DPPH method revealed $\mathrm{IC}_{50} \sim 29.61 \mathrm{ppm}$ of ethanol fraction, $23.15 \mathrm{ppm}$ of buthanol fraction, and $17.27 \mathrm{ppm}$ of ethyl acetic fraction (Indah et al., 2013).

Therefore, current study aims to determine antidiabetic activity of ethanolic extract of Kalanchoe pinnata in alloxan-induced diabetic rats.

\section{MATERIALS AND METHODS}

Kalanchoe pinnata leaves were collected from Kawasan Puspiptek Serpong and were authenticated by Research Center for Biology, Indonesian Instititute of Sciences (LIPI).

\section{Preparation of plant extracts}

The leaves were dried using blower oven $<50^{\circ} \mathrm{C}$ for $24 \mathrm{~h}$, crushed, and extracted using $70 \%$ ethanol $(3 \times 24 \mathrm{~h}$ maseration). Ethanol extracts obtained were then concentrated in rotary evaporator under vacuum. The yield of ethanolic extract of Kalanchoe pinnata (KP) dry leaves was $15.7 \%$.

\section{Animals}

The Male Sprague Dawley rats (150$350 \mathrm{~g}$ ) were procured from Fakultas Kedokteran Hewan IPB, Bogor and housed under standard conditions of temperature and relative humidity with $12 \mathrm{~h}$ light/dark cycle. Animals were fed on standard commercial pellet diet and water ad libitum. The ethical clearance of the experiment has been approved by Health Research Ethics Commitee, Universitas Indonesia and Cipto Mangunkusumo Hospital, Indonesia (Ethical clearance certificate number: 663/UN2.F1/ ETIK/2016).

\section{Induction of diabetes}

Induction of diabetes was performed according to Misra and Aiman (2012), with modification. Base line FBG was measured before alloxan injection $(\mathrm{t}(-1))$. Alloxan monohydrate (Sigma Aldrich; stored at $4^{\circ} \mathrm{C}$ ) was dissolved in normal saline at room temperature (freshly prepared) and injected to 30 overnight fasted male Sprague-Dawley rats at a dose of $150 \mathrm{mg} / \mathrm{kg}$ intraperitonially. The animals were then kept for the next 7 days on $10 \%$ glucose after alloxan administration. After $72 \mathrm{~h}$ of alloxan injection $(\mathrm{t} 0), \mathrm{FBG}$ was determined using GlucoDr glucometer strips. Animals with FBG $>200 \mathrm{mg} / \mathrm{dL}$ were considered to have developed experimental diabetes as shown by hyperglycaemia state. Then, FBG was measured every 5 days recorded as $t 1, t 2$, and $t 3$ to determine fluctuations in FBG. Blood was collected from tail vein. As standard reference, Glibenclamide was given at a dose of $1.35 \mathrm{mg} / \mathrm{kg}$ orally per day, while Acarbose was given at a dose of $13.5 \mathrm{mg} / \mathrm{kg}$ orally per day.

\section{Animal experimentation}

In the present study the animals were distributed into 7 groups $(n=5)$ as follows:normal control, HG (hyperglycaemia), $\mathrm{HG}+\mathrm{KPE}$ high-dose (hyperglycaemia+ $\mathrm{KPE} \quad 33.2 \mathrm{mg} / \mathrm{kg}), \mathrm{HG}+\mathrm{KPE}$ medium-dose (hyperglycaemia+KPE $11.6 \mathrm{mg} / \mathrm{kg}$ ), $\mathrm{HG}+\mathrm{KPE}$ low-dose (hyperglycaemia+KPE $5.8 \mathrm{mg} / \mathrm{kg}$ ), standard drug 1 (hyperglycaemia+ glibenclamide $1.35 \mathrm{mg} / \mathrm{kg}$ ), standard drug 2 (hyperglycaemia+acarbose $13.5 \mathrm{mg} / \mathrm{kg}$ ). The study was conducted for 15 days to evaluate the potential of the extracts to lower FBG level. Body weights of the rats were monitored weekly during the study period.

\section{Pancreas histological observation}

Pancreas histological observation was conducted on day 15, at the end of the experimental period. Rats were euthanized by ether and the pancreas were collected and fixed with bouin's solution for $24 \mathrm{~h}$. The pancreas was then stained with Hematoxylin eosin (HE) for observation of number of beta cell Langerhans. 
Tabel I. Effect of KPE on FBG during study

\begin{tabular}{lccccc}
\hline \multirow{2}{*}{ Group } & \multicolumn{5}{c}{ FBG \pm SD (mg/L) } \\
\cline { 2 - 6 } & $\mathbf{t ~ ( - 1 )}$ & To & $\mathbf{t 1}$ & $\mathbf{t} 2$ & $\mathbf{t 3}$ \\
\hline Normal & $103.67 \pm 15.33$ & $117.92 \pm 8.07$ & $107.83 \pm 7.15$ & $97.42 \pm 13.75$ & $93.5 \pm 8.24$ \\
HG & $115 \pm 2.45$ & $429 \pm 106.88$ & $267 \pm 106.10$ & $207 \pm 104.24$ & $130 \pm 16.85$ \\
HG+KPE (high dose) & $112.2 \pm 12.76$ & $384 \pm 137.48$ & $174.6 \pm 111.84$ & $111.2 \pm 24.22$ & $116 \pm 13.93$ \\
HG+KPE (medium dose) & $112 \pm 10.05$ & $259.4 \pm 48.53$ & $134.4 \pm 30.00$ & $115.8 \pm 17.88$ & $116.2 \pm 10.40$ \\
HG+KPE (low dose) & $112.2 \pm 6.57$ & $353.8 \pm 163.69$ & $142.4 \pm 35.67$ & $113.6 \pm 16.36$ & $124.6 \pm 10.26$ \\
HG+ Acarbose & $109.5 \pm 16.99$ & $262 \pm 36.79$ & $121.83 \pm 22.25$ & $105.67 \pm 14.51$ & $97 \pm 8.65$ \\
\hline
\end{tabular}

\section{Statistical analysis}

Numeric data were expressed as mean \pm SD. Data were analyzed using one-way analysis of variance $(A N O V A)(p<0.05)$ followed by Multiple LSD.

\section{RESULTS DISCUSSION}

Base line FBG (t(-1)) was determined before alloxan injection. All rats showed normal FBG with no significant difference among the groups (Table I, Figure 1).

Three days after alloxan injection $(\mathrm{t} 0)$, hyperglycaemia state was confirmed by FBG $>200 \mathrm{mg} / \mathrm{dL}$ in all the rats. However, FBG increase was not significant in $\mathrm{HG}+\mathrm{KPE}$ medium dose group and acarbose group compared to normal group. Meanwhile, no significantly difference was observed among groups that received alloxan injection.

FBG reduction were detected after 5 days (t1) alloxan injection in all groups. While 5 days treatment brought FBG to a level $<200 \mathrm{mg} / \mathrm{dL}$ in all groups, HG groups remained suffered from hyperglycaemia as shown by FBG $>200 \mathrm{mg} / \mathrm{dL}$. As a result, only HG group differed significantly from normal group. In the other hand, all treatment reduced FBG significantly, but not high-dose KPE.

Ten days after treatment ( $\mathrm{t} 2)$, all rats' FBG kept decreasing. However, HG group remained in hyperglycaemia state as shown by FBG $>200 \mathrm{mg} / \mathrm{dL}$. As a result, only HG group differed significantly from normal group and all treatments reduced FBG significantly.

Fifteen days after treatment, all rats' FBG went back to normal as shown by FBG $<200 \mathrm{mg} / \mathrm{dL}$. However, only standard treatment (glibenclamide or acarbose) reduced FBG similar to normal while KPE treatment did not reduced FBG significantly.

Histological observation using $\mathrm{HE}$ staining showed that all treatment, but $\mathrm{KPE}$ high-dose, improved the morphology of $\beta$ cells in comparison to the HG group based on the number of cell (Figure 2). However, only KPE medium and low dose increased the number of $\beta$ cells significantly.

K. pinnata has traditionally been used as medicinal plant to treat various ailments around the world, including diabetes (Patil et al., 2013). Therefore, several study have been conducted to evaluate its bioactivity, such as antidiabetics, anticonvulsant, antinociceptive, antiedematogenic, antiinflammatory, anticancer and antiHPV, antileishmanial (Patil et al., 2013; Mora-Perez et al., 2016; Ferreira et al., 2014; Mahata et al., 2012; Muzitano et al., 2006).

K. pinnata leaves contain anthocyanins that considered responsible for its antidiabetic, anticancer, cardiovascular, and neurological activity (Cruz et al., 2012). Anthocyanins are water soluble flavonoid compounds that gives color in plant (Cruz et al., 2012). Phytochemistry study of the KPE used in this study revealed flavonoids and steroids compound and isolated quercetin glycosides (Fajriyah, 2011).

We suggest that the bioactivity of $K$ pinnata in reducing FBG and improving morphology of the islets of Langerhans and $\beta$ cells were caused by its various natural compounds constituent, for example quercetin through antioxidant mechanism (Figure 3). 
Tri Yuliani

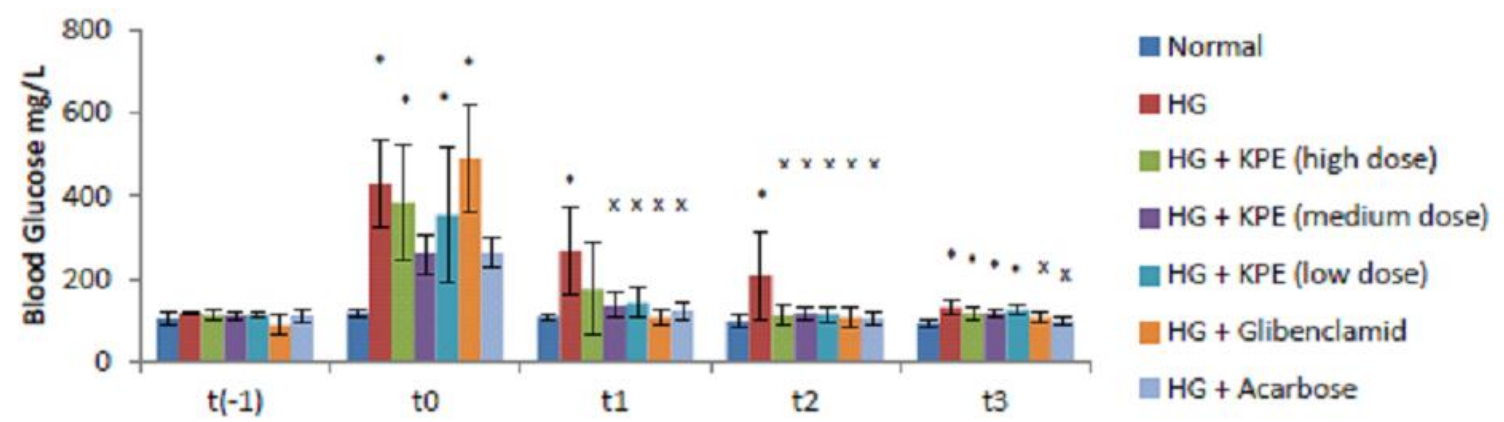

Figure 1. Effect of KPE treatment on FBG level in alloxan induced rat. HG=Alloxan, $\mathrm{KPE}=$ Kalanchoe pinnata extract, high dose $=33.2 \mathrm{mg} / \mathrm{kg} \mathrm{BW}$, medium dose $=11.6 \mathrm{mg} / \mathrm{kg} \mathrm{BW}$, low dose $=5.8 \mathrm{mg} / \mathrm{kg}$ BW, Glibenclamide $=1.35 \mathrm{mg} / \mathrm{kg}$ bw, Acarbose $=13.5 \mathrm{mg} / \mathrm{kg} \mathrm{BW} . \mathrm{t}(-1)$ $=$ base line, $\mathrm{t} 0=$ after alloxan injection, $\mathrm{t} 1$ or $\mathrm{t} 2$ or $\mathrm{t} 3=5$ or 10 or 15 days after test sample administration. Data are expressed as mean $\pm \mathrm{SD} . * \& \mathrm{x}, \mathrm{p}<0.05$ (* indicates comparison between normal and HG; $\mathrm{x}$ indicates comparison between HG and treatments).

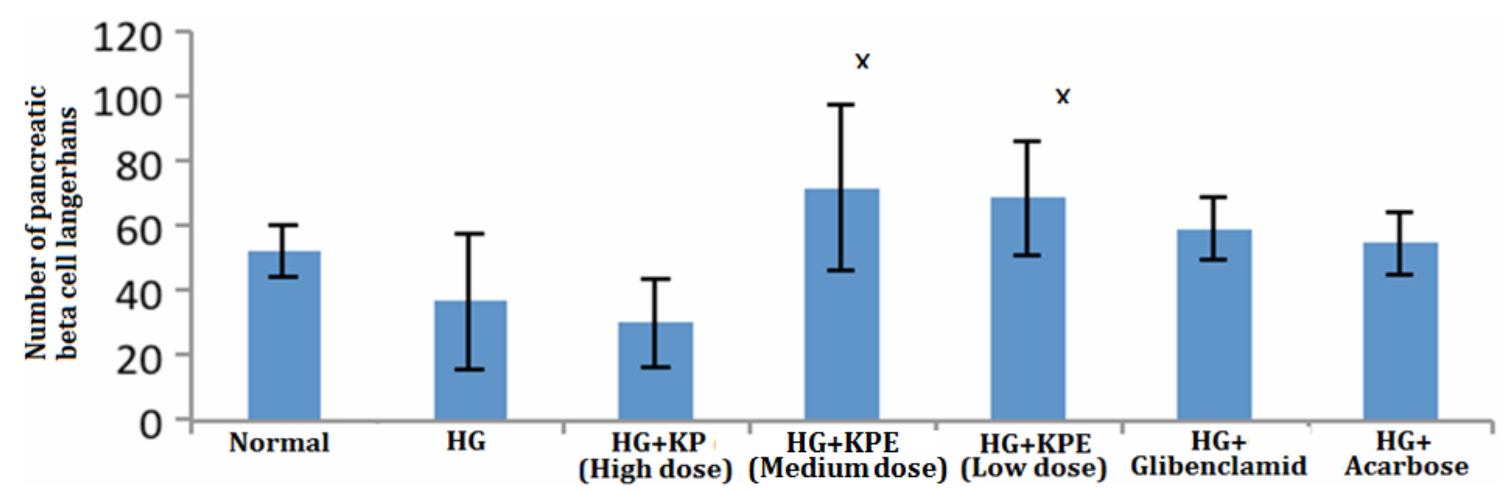

Figure 2. Effect of KPE treatment on number of pancreatic beta cell langerhans in alloxan induced rat. $\mathrm{HG}=$ Alloxan, $\mathrm{KPE}=$ Kalanchoe pinnata extract, high dose $=33.2 \mathrm{mg} / \mathrm{kgbw}$, medium dose $=11.6$ $\mathrm{mg} / \mathrm{kg}$ bw, low dose $=5.8 \mathrm{mg} / \mathrm{kg} \mathrm{bw}$, Glibenclamide $=1.35 \mathrm{mg} / \mathrm{kg} \mathrm{bw}$, Acarbose $=13.5 \mathrm{mg} / \mathrm{kg}$ bw. $x, p<0.05$. ( $x$ indicates comparison between $H G$ and treatments).

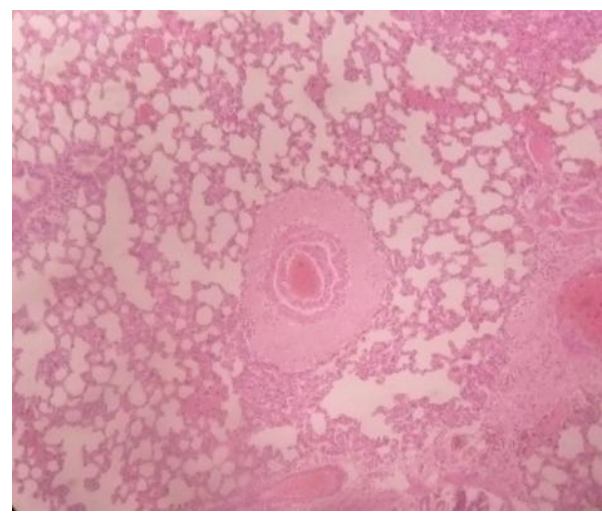

Figure 3. Pancreatic $\beta$ cell Langerhans stained with Hematoxylin eosin (HE). 
It is worth noting that oxidative stress plays a role in the pathogenesis of diabetes mellitus. Hyperglycaemia was characterized with increase oxidative stress leading to defect in insulin action and insulin secretion. Quercetin as antioxidants reduced oxidative stress leading to protection of $\beta$ cells of the pancreas resulted in the increase of insulin production and decreased of FBG. Several studies reported quercetin mechanism of action in diabetes such as decreases lipid peroxidation, increases antioxidant enzymes activity, inhibits insulindependent activation of phosphoinositol-3kinase (PI-3K), and reduces intestinal glucose absorption by inhibiting GLUT (Sunarwidhi et al., 2014).

Based on pharmacological and histopathological studies, we suggested that the hypoglycemic effect of KPE was optimum at medium dose (11.6mg/kg bw).

However, it is difficult to conclude that hypoglycemic activity of KPE in this study is only caused by quercetin. Various active compounds in KPE may synergistically increase hypoglycemic effect.

Therefore, the mechanism of action of each active compounds in the extract needs further investigation, including immuno histochemical observation on pancreatic insulin expression.

\section{CONCLUSION}

This study showed that KPE possesed bioactivity in lowering blood glucose and improving the morphology of $\beta$ cells of Langerhans islet. KPE is potential to be developed as a blood glucose-lowering agent for diabetic patients.

\section{ACKNOWLEDGMENTS}

We thank the "Program Insentif Riset Peneliti dan Perekayasa Tahun 2011" for financial support in the study.

\section{REFERENCES}

Abdulazeez SS. 2013. Diabetes treatment: A rapid review of the current and future scope of stem cell research. Saudi Pharm. J. 23: 333-340.

Cruz BP., Chedier LM., Peixoto PHP.,Fabri RL., Pimenta DS. 2012. Effects of light intensity on the distribution of anthocyanins in Kalanchoe brasiliensis Camb. and Kalanchoe pinnata (Lamk.) Pers, Anais da Academia Brasileira de Ciências. 84(1): 211-217

Domingueti CP., Dusse LM., Carvalho MD., de Sousa LP., Gomes KB., Fernandes AP. 2015. Diabetes mellitus: The linkage between oxidative stress, inflammation, hypercoagulability and vascular complications. J Diabetes Complications. Dec 18.

Ferreira RT., Coutinho MAS., CarmoMalvar D., Costa EA., Florentino IF., Costa SS., Vanderlinde FA. 2014. Mechanisms Underlying the Antinociceptive, Antiedematogenic, and AntiInflammatory Activity of the Main Flavonoid from Kalanchoe pinnata.Evidence-Based Complementary and Alternative Medicine: 429256.

Global status report on noncommunicable diseases. 2014. Geneva, World Health Organization.

Hossain MK., Dayem AA., Han J., Saha SK., Yang G., Choi HY., Cho S. 2016. Recent Advances in Disease Modeling and Drug Discovery for Diabetes Mellitus Using Induced Pluripotent Stem Cells. Int. J. Mol. Sci. 17: 256.

Indah DD., Euis F, Megawati, Tri Y. 2012. The Antidiabetic Activity of Cocor Bebek Leaves' (Kalanchoe pinnata Lam.Pers.) Ethanolic Extract from Various Areas. J.Trop. Life Sciences. 2(2) : $37-39$.

Kementrian Kesehatan RI. Badan Penelitian dan Pengembangan. Riskesdas. 2013. Jakarta.

Mahata S., Maru S., Shukla S., Pandey A., Mugesh G., Das BC., Bharti AC. 2012. Anticancer property of Bryophyllum pinnata (Lam.) Oken. leaf on human cervical cancer cells. BMC Complementary and Alternative Medicine. 12:15

Misra M. and Aiman U. 2012. Alloxan: An unpredictable drug for diabetes induction? Indian J Pharmacol.44(4): 538539.

Muzitano MF, Tinoco LW, Guette C, Kaiser CR, RossiBergmann B, Costa SS. The antileishmanial activity assessment of unusual flavonoids from Kalanchoe 
pinnata. Phytochemistry, 2006; 67: 20712077

Patil SB., Dongare VR., Kulkarni CR., Joglekar MM., Arvindekar AU. 2013 Antidiabetic activity of Kalanchoe pinnata in streptozotocin-induced diabetic rats by glucose independent insulin secretagogue action. Pharm Biol. 51(11):1411-8.

Sharma SB., Gupta R. 2015. Drug development from natural resource: a systematic approach. Mini Rev Med Chem. 15(1):52-7.

Sunarwidhi AL., Sudarsono S., Nugroho AE. 2014. Hypoglycemic Effect of Combination of Azadirachta indica A. Juss. and Gynura procumbens (Lour.) Merr.
Ethanolic Extracts Standardized by Rutin and Quercetin in Alloxan-induced Hyperglycaemia Rats. Adv Pharm Bull. 4(Suppl 2): 613-618.

Szkudelski T. 2001.The Mechanism of Alloxan and Streptozotocin Action in B Cells of the Rat Pancreas. Physiol. Res. 50: 536546.

Verma RK., Mishra G., Singh P., Jha KK., Khosa RL. 2015. Anti-diabetic activity of methanolic extract of Alpinia galanga Linn. aerial parts in streptozotocin induced diabetic rats. Ayu. 36(1):91-95. 